\title{
PEDAGOGI USUL AL FIQH BERBASIS PENDIDIKAN PERDAMAIAN DI ERA MULTIKULTURAL
}

\author{
Rusli \\ STAIN Datokarama Palu \\ Jalan Diponegoro No. 23 Palu Sulawesi Tengah. 94221. \\ Telp.081578827127, email: rusli_mochtar@yahoo.com.
}

\begin{abstract}
This article discusses the role of usul al figh in constructing humanist values and principles to build 'peace education' in the current multicultural era. Usul al figh is considered as the source of value and change, and has played a significant role to start reforms in legal and social institutions because of the pressures of context and religious integrity. The values contained in the sources of Islamic law, such as al Quran, Sunnah, ijma>, qiyas, istislah, istihsan, sadd al dhara $>i$, and also maqasid al shari>ah, are translated into the community and are wholly implemented in the educational institutions. These values are transmitted to the learners through methods such as dialogue, cooperation, problem solving and the democratic limit creation. In transferring knowledge and values, an educator must be grounded on two important approaches: first, encouraging respect to the diversity based on the concept that education as a mirror, window, and conversation; second, doing class activity which is more cooperative based on the principle of justice and equality.
\end{abstract}

Artikel ini membahas tentang peran ushul al figh dalam mengkonstruk nilai-nilai dan prinsip-prinsip yang humanis untuk membangun pendidikan perdamaian (peace education) di era multikultural saat ini. ushul al figh dipercaya sebagai sumber nilai dan perubahan, dan telah memainkan peran yang signifikan dalam memulai reformasi-reformasi dalam bidang hukum dan pranata sosial karena adanya tekanan-tekanan konteks dan integritas keagamaan. Nilai-nilai yang terdapat dalam sumber hukum Islam, seperti al Quran, Sunnah, ijma', qiyas, istislah, istihsan, sadd al dhara'i', dan juga maqasid al shari'ah, diterjemahkan 
ke dalam masyarakat dan diterapkan secara menyeluruh di dalam lembagalembaga pendidikan. Nilai-nilai ini ditransmisikan kepada para peserta didik melalui metode-metode seperti dialog, kerja sama, pemecahan masalah dan pembuatan batasan yang demokratis. Dalam mentransfer pengetahuan dan nilai-nilai ini, seorang pendidik harus berpijak pada dua pendekatan yang sangat penting yaitu; pertama, mendorong sikap hormat terhadap perbedaan, dengan berpijak pada konsep bahwa pendidikan sebagai cermin (mirror), jendela (window), dan percakapan (conversation); kedua, melakukan aktivitas kelas yang lebih kooperatif berbasis pada asas keadilan dan persamaan.

Key words: usul al figh, peace education, dialogue, cooperation, problem solving

\section{Pendahuluan}

Usul al figh merupakan satu disiplin inti dalam kajian-kajian syariah, terutama terkait dengan metode penalaran hukum, selain al qawa' id al fiqhiyyah (legal maxims). Di berbagai perguruan tinggi Islam, pemasukan disiplin ilmu ini ke dalam kurikulum adalah sangat penting. Signifikansi tersebut terletak pada fakta bahwa usul al fiqh mencakup prinsip-prinsip metodologis yang sangat mendasar dalam proses penetapan hukum Islam. Dengan kata lain, usul al figh dipercaya sebagai alat dan mekanisme dalam proses deduksi tersebut. Jika alat ini tidak dapat digunakan dengan tepat, maka akan muncul aturan-aturan hukum yang tidak konsisten dalam pandangan ulama. Untuk mengembangkan ilmu-ilmu keislaman, pengkajian terhadap disiplin ini diberikan perioritas yang tinggi. Metode ini disusun dalam berbagai pendekatan yang berbeda untuk menyesuaikan kebutuhan-kebutuhan yang berbeda dari masa-masa yang berbeda.

Istilah usul al figh, yang terambil dari dua akar kata usul (plural: asl) dan figh, dipahami sebagai "mengetahui dalil-dalil fiqih secara umum, mekanisme penetapan hukum syariat darinya, dan kondisi seorang yang mengeluarkan dalil” (al Namlah, I, 1999: 29). Ulama Shafi'iyyah mengartikannya sebagai "pengetahuan tentang dalil-dalil fiqih secara umum, mekanisme pengambilannya, dan kondisi mujtahid" (al Zuhayli, I, 1986: 23). Secara lebih rinci, dalil-dalil yang menjadi objek kajian usul al fiqh dapat dibedakan ke dalam dua bagian penting: pertama, dalil-dalil yang disepakati (al adillah al muttafaq 'alayha), yang mencakup al Quran, Sunnah, ijma' dan qiyas, dan kedua, dalil-dalil yang diperselisihkan (al adillah al mukhtalaf fiha), yang mencakup metode-metode seperti istihsan, istishab, maslahah mursalah, sadd al dhara'' $i$ ', madhhab al sahabi, al 'urf, shar' man qablana, dan sebagainya (al Zuhayli, 1986, I: 417-816; II, 733-914). 
Meskipun metode-metode penalaran dan penetapan hukum ini sangat berperan dalam menelurkan corak fiqih yang berwarna dalam berbagai kitab fiqih klasik yang melimpah, namun sayangnya pengajaran dalil-dalil dan metode fiqih di berbagai perguruan tinggi Islam masih menggunakan metode konvensional tradisional. Sebagian pengajar kerapkali hanya sekadar memaparkan metode-metode ini seperti apa adanya, tanpa menempatkannya dalam konteks yang senantiasa berubah. Atau dengan kata lain, pengajaran usul al fiqh di berbagai perguruan tinggi masih berada dalam paradigma behavioristik; dalam arti masih bersifat normatif, kehilangan modul standar yang lebih merespons dan menyesuaikan perkembangan zaman. Padahal perubahan epistemologi pengetahuan dapat menciptakan perubahan-perubahan dalam hukum (Shahrur, 2000: 16). Di sinilah pentingnya penggunaan paradigma konstruktivistik. Fakta yang tidak dapat ditolak adalah bahwa dunia ini mengalami perkembangan yang sangat pesat lantaran perkembangan teknologi informasi, terutama melalui media Internet. Sebagai akibatnya, muncul isu-isu global dalam beragam bentuknya. Bahkan fatwa, yang nuansa sakralnya begitu dominan, mulai masuk ke wilayah online, yang secara sosial keagamaan mengancam otoritas tradisional.

Di sisi lain, persoalan-persoalan sosial, dalam bentuk kekerasan sosial, baik dipicu oleh faktor etnik, agama, atau lainnya, menjadi sebuah fenomena umum di dunia, termasuk Indonesia. Akibat yang ditimbulkan dari kekerasan ini adalah begitu serius. Banyak upaya yang sudah dilakukan oleh berbagai pihak, baik pemerintah, organisasi kemasyarakatan, maupun tokohtokoh adat dan agama, untuk melakukan resolusi konflik dan rekonsiliasi, namun kekerasan dalam realitasnya masih tetap berlangsung. Islam sebagai religion of peace ditantang untuk membuktikan perannya dalam konteks ini. Usul al fiqh sebagai bagian dari disiplin keilmuan yang menjadi unsur yang menopang Islam tentu perlu melakukan pembenahan diri dengan menelurkan nilai-nilai yang dapat berperan menciptakan pendidikan perdamaian (peace education). Dalam konteks ini, persoalan utama yang akan dibahas adalah bagaimana usul al figh berperan mengusung nilai-nilai perdamaian tersebut. Persoalan utama ini dielaborasi menjadi beberapa pertanyaan berikut: Prosedur, metode dan materi usul al figh seperti apa yang dapat dikembangkan menjadi nilai-nilai perdamaian? Kemudian, yang terpenting, bagaimana mengajarkan nilai-nilai tersebut di dalam kelas? 


\section{Usul al Fiqh sebagai Sumber Nilai dan Perubahan}

Fiqih dan seperangkat metodologinya (usul al fiqh) diasumsikan sebagai sumber bagi nilai dan perubahan. Dengan asumsi ini, fiqih dan usul al fiqh dipercaya berpotensi melakukan reformasi praktis dalam berbagai aspek kehidupan. Asumsi ini dipertegas oleh pernyataan Hallaq bahwa "dalam hukum Islam, otoritas senantiasa melibatkan kekuatan untuk menggerakkan proses continuity (kesinambungan) dan change (perubahan)" (Hallaq, 2001: ix). Secara historis, hukum Islam memang telah memprakarsai berbagai reformasi karena adanya berbagai tekanan kontekstual dan integritas keagamaan. Prinsip-prinsip hukum menyimpan kekuatan moral melalui konsep-konsep yang menjamin bahwa "perubahan hukum tidak hanya terjadi melalui satu cara yang khusus namun melekat dalam berbagai proses yang dibangun ke dalam struktur hukum" (Hallaq, 2001: 204).

Secara teknis, fiqih terkadang membentuk catatan historis tentang metode yang digunakan para fukaha dalam memecahkan berbagai persoalan dengan cara dialog dengan berbagai otoritas tradisional. Sebagai metode penalaran hukum, usul al figh adalah sebuah tren penalaran hukum praktis yang selalu hidup dan berhasil disesuaikan dengan berbagai kondisi, dan menawarkan berbagai kaidah untuk memperluas kemampuan dan jangkauan Islam dalam menghadapi berbagai macam tantangan sosial yang baru. Dengan seperangkat kaidah dan prinsip hukum yang ada dalam usul al figh ini, diasumsikan bahwa persoalan-persoalan yang terjadi di era kontemporer dapat diselesaikan dengan baik, termasuk berbagai persoalan kekerasan sosial yang semakin menjamur di dunia yang semakin modern dan mengglobal ini. Prinsip-prinsip yang akan diulas dalam tulisan ini mencakup persoalan dalil-dalil hukum dan maqasid al shari'ah.

\section{Sumber Hukum (Masadir al Ahkam)}

Istilah masadir al ahkam seringkali disebut adillah al ahkam (dalil hukum). Dalam tradisi usul al figh, sumber hukum adalah Allah sebagai pembuat hukum (shari $)^{\prime}$. Allah menyatakan keinginan dan aturan-aturan hukum-Nya, dan untuk mengetahuinya diperlukan petunjuk (dalil) hukum. Di kalangan ulama usul al figh, dalil-dalil hukum ini mencakup dalil-dalil yang disepakati (al adillah al muttafaq 'alayha) dan dalil-dalil yang diperselisihkan (al adillah al mukhtalaf fiha). Dalam istilah lain, disebut sumber pokok (masadir asasiyyah) dan sumber pengikut (masadir taba'iyyah). Yang pertama terdiri dari al Quran, Sunnah, ijma' dan qiyas, sedangkan yang kedua mencakup metode istihsan, 
istishab, istislah atau maslahah mursalah, sadd al dhara' $i$ ', 'urf, shar' man qablana, madhhab al sahabi, dan lainnya. Bahasan berikut akan mengulas sebagian dari dalil hukum, seperti al Quran, Sunnah, qiyas dan istislah sebagai prinsipprinsip hukum teoritis yang mendasari asas perdamaian atau gerakan anti kekerasan.

\section{Al Quran dan Sunnah sebagai Teks Dasar}

Al Quran dipercaya sebagai sebuah teks dasar yang memuat nilainilai perdamaian. Al Quran merupakan ekspresi dari kehendak Allah, yang termanifestasikan dalam konsep-konsep yang ditawarkannya. Dalam al Quran, banyak konsep yang merujuk kepada prinsip perdamaian atau nir-kekerasan ini. Bahkan, al Quran itu sendiri secara umum mengarah kepada perdamaian, dan ini diperkuat oleh nabi dalam praktik kehidupan sehari-hari sebagai penyampai al Quran. Di antara konsep-konsep tersebut adalah konsep salam atau silm, yang mengandung arti "damai" dan "keselamatan". Dari kata ini muncul konsep islam (penyerahan diri), dan orang yang melakukan penyerahan diri secara total kepada Allah disebut muslim. Sebutan muslim diberikan kepada seorang yang, untuk mencapai kedamaian, menyerahkan keinginannya kepada Sang Pencipta dengan menjadikan semua perilaku, melalui pilihan-pilihannya sendiri, sesuai dengan kode etis Islam yang diindikasikan dalam al Quran dan Sunnah ketimbang keinginannya sendiri.

Secara teologis, justifikasi untuk posisi konseptual "perdamaian" dalam Islam terletak pada sifat Tuhan, kualitas spiritual yang diatribusikan kepada zat-Nya, al salam (QS al Hashr: 23). Oleh karena itu, Tuhan menyediakan kedamaian batin buat orang yang diberikan petunjuk (lahum dar al salam 'inda rabbihim) (QS al An'am: 125-127), dan menyambut para mukmin sejati ke dalam surganya dengan kalimat "Masuklah ke dalam surga dengan penuh kedamaian (udkhuluha bi-salam) (QS Qaf: 31-34)," dan perkataan penduduk surga adalah "salam, salam" (QS al Waqi'ah: 26). Dalam kehidupan akhirat, ketika mereka menyambut penduduk surga, mereka berkata, "Kesejahteraan buat kalian karena kesabaran kalian (salam 'alaykum bima sabartum)" (QS al Ra'd: 24). Selain itu, Tuhan juga memberikan doa keselamatan dan kedamaian buat Nabi dan memerintahkan umat Islam untuk mengirimkan doa yang sama (QS al Ahzab: 36).

Dalam kaitan dengan persoalan-persoalan sosial dan politik, gagasan fungsional tentang "perdamaian" memainkan peran pentingnya dalam menentukan karir dan perilaku Nabi terhadap orang-orang yang dihadapinya. Ini 
kerapkali direfleksikan dalam surat-surat yang membahas tentang interaksinya dengan suku-suku Arab (Waugh, IV, 2004: 33-34). Sebagai manifestasi dari konsep salam, Nabi melakukan rekonsiliasi (islah) dengan penuh keadilan dalam kasus sengketa dan konflik yang terjadi di antara umat beriman (QS al Hujurat (49): 9). Nabi bersikap toleran terhadap penganut agama lain, tidak menghina ritual dan menghancurkan rumah-rumah ibadah mereka.

Dalam peperangan, tindakan kekerasan yang dilakukan oleh Nabi adalah pada kondisi-kondisi tertentu, seperti, ketika ia dan para pengikutnya diserang dan tidak ada cara lain untuk menghentikan para penyembah berhala Mekkah. Dalam al Quran disebutkan, "Balasan suatu kejahatan adalah kejahatan yang serupa. Barangsiapa yang memaafkan dan berbuat baik, maka pahalanya adalah tas tanggungan Allah ..." (QS al Shura: 40). Ayat ini memberikan indikasi bahwa meskipun nabi membela diri dari para penyerang, ia sering memberikan maaf, bahkan terhadap musuh-musuhnya. Fakta ini diperkuat oleh sebuah Hadits tentang Ghawras dalam peperangan Ghatfan dan Anmar. Singkatnya, perdamaian adalah bagian yang integral dari agama Islam. Teks al Quran dan praktik Nabi memperlihatkan atau memberikan justifikasi sederhana bahwa "perdamaian" merupakan komponen yang fundamental dalam relasi Tuhan dengan manusia, atau manusia dengan sesamanya dan lingkungan sekitarnya.

\section{Qiyas (Penalaran Analogis)}

Metode qiyas merupakan salah satu alat terpenting untuk membahas tantangan-tantangan baru dalam persoalan kekerasan sosial dengan menggunakan sumber-sumber tradisional. Dalam tradisi usul al fiqh, qiyas diartikan sebagai "proses penghubungan satu kasus yang tidak ada ketetapan hukumnya dalam nas dengan kasus yang mempunyai ketentuan hukumnya dalam nas karena adanya persamaan illat hukum" (al Zuhayli, I, 1986: 603). Dalam metode ini, yang terpenting adalah menentukan illat yang valid untuk menetapkan suatu hukum, dan illat adalah dasar bagi sebuah hukum. Selain sebagai rukun qiyas, pencarian illat hukum (ta'lil al ahkam) juga merupakan asas utama dalam memahami dan menyelami maqasid al shari'ah yang sebenarnya.

Dalam kaitan ini, ada beberapa metode yang biasa digunakan oleh ulama usul, di antaranya, al sabr wa al taqsim, al munasabah, tanqih al manat. Yang pertama, al sabr wa al taqsim, mengandung pengertian "mengumpulkan sifat-sifat yang mungkin dijadikan sebagai illat dan membagi-baginya, kemudian mengujinya untuk menyingkirkan sifat-sifat yang tidak sesuai untuk dijadikan 
illat dan mempertahankan sifat-sifat yang sesuai untuk dijadikan illat." (al Sa'di, 2000: 444; Sanu, 2000: 230). Seorang mujtahid melakukan pengumpulan dan pembatasan terhadap sifat-sifat yang dapat dijadikan illat, yang melintas di benaknya. Kemudian mengujinya dengan alat ukur yang digunakan untuk melihat sifat yang cocok (al wasf al munasib) untuk dijadikan illat. Selanjutnya, menghilangkan sifat-sifat yang tidak sesuai menurut kaidah-kaidah penetapan illat. Kedua, al munasabah, yaitu antara sifat dan hukum ada kesesuaian sehingga penetapan hukum tersebut berakibat pada terwujudnya kemaslahatan yang diinginkan oleh Allah, yaitu memunculkan kemaslahatan dan menolak kerusakan (al Zuhayli, I, 1986: 676). Dan ketiga, tanqih al manat yaitu menyaring satu alasan hukum dengan cara meniadakan perbedaan antara satu dengan yang lainnya.

Melalui proses-proses ini, qiyas mungkin dapat memperlihatkan bagaimana masalah-masalah kekerasan yang terjadi kepada manusia dan lingkungan, mempunyai sifat-sifat yang sama dengan masalah-masalah yang dibahas dalam al Quran atau Sunnah. Misalnya, tentang persoalan pembuangan sampah besar-besaran ke pantai atau laut, yang tidak ada ketentuan hukumnya secara eksplisit dalam kitab suci. Namun, ada sebuah Hadits Nabi yang melarang manusia untuk buang air kecil di saluran air atau air yang menggenang (Muslim, I, 1991: 235). Karena kedua kasus ini mempunyai sifat yang sama, yaitu "membuang sampah secara langsung ke dalam air", lalu hukumnya bisa diperluas kepada kasus yang baru. Hadits memang tidak menyebutkan illat tentang keharamannya. Maka, kita dapat menyimpulkan apa yang salah dengan "buang air di saluran air". Dengan prosedur al sabr wa al taqsim, alasan-alasan yang mungkin dapat dihadirkan adalah, misalnya, mengancam kesehatan manusia, atau memasukkan kotoran ke dalam wilayah masyarakat, atau membuang sampah, atau mencemari sumber ekologis yang sangat penting. Hanya illat yang terakhir ini yang mungkin lebih sesuai untuk diterapkan pada kasus membuang sampah secara besar-besaran ke dalam sungai, pantai atau lautan. Berdasarkan illat yang sama ini, maka perbuatan membuang sampah ke dalam sungai, pantai, atau lautan adalah dilarang dan diharamkan (Jenkins, 2005: 347). Persoalan-persoalan kekerasan lain dapat pula dicarikan hukumnya melalui proses qiyas kepada kasus-kasus yang sudah mendapatkan ketentuan hukumnya yang jelas (sarih) dalam al Quran atau Sunnah.

\section{Istislah dan Maqasid al Shari'ah}

Mengartikan maslahah sebagai "penjagaan terhadap agama, jiwa, akal, 
keturunan dan harta." Menurutnya, "segala sesuatu yang mengantarkan kepada pemeliharaan terhadap lima prinsip dasar ini dianggap sebagai maslahah, dan sebaliknya, segala yang menyebabkan hilangnya prinsip-prinsip dasar ini disebut mafsadah; menghilangkannya disebut juga maslahah." Oleh karena itu, secara umum dapat dikatakan bahwa syariah dalam semua aspeknya bertujuan untuk menciptakan kemaslahatan dan kebaikan buat individu dan masyarakat, dan melindungi mereka dari segala bentuk kerusakan dan kehancuran (Al Ghazali, 1993, II: 481-482, 502-503). Berbagai hukum taklifi seperti wajib, mandub dan mubah pada hakikatnya ditujukan untuk mewujudkan datangnya manfaat dan kemaslahatan, sedangkan makruh dan haram ditujukan untk mencegah terjadinya kerusakan dan kejahatan (Kamali, 2008: 33). Maka, segala yang meningkatkan kesejahteraan buat masyarakat, dari sudut pandang syariah, dapat disebut maslahah, dan yang mengurangi serta menghilangkannya disebut mafsadah.

Secara umum, maslahah dapat diklasifikasikan ke dalam tiga kategori: daruriyyah, hajiyyah dan tahsiniyyah. Yang pertama bersifat esensial untuk menjaga lima prinsip seperti yang disebutkan di atas, sedangkan yang kedua tidak begitu penting dalam memelihara lima prinsip dasar, namun penting untuk menghilangkan kesulitan-kesulitan dalam hidup. Dan yang terakhir lebih bersifat komplementer, yang ketidaannya tidak menyebabkan kesulitan dalam hidup. Sementara itu, maqasid al shari'ah mengandung pengertian "maksud dan tujuan pembentukan syariah" yaitu "mewujudkan kemaslahatan dan menolak kemudaratan." Konsep maslahah dan maqasid al shari'ah dapat dikatakan relatif sama. Namun, jika dilihat secara lebih seksama, dua konsep ini pada dasarnya saling melengkapi. Maqasid al shari'ah berkaitan dengan perlindungan terhadap unsur-unsur dasar yang melekat pada manusia, sementara maslahah terkait dengan tingkatan perlindungan terhadap unsur-unsur tersebut. Jika dibuat skema, maka akan terlihat seperti ini:

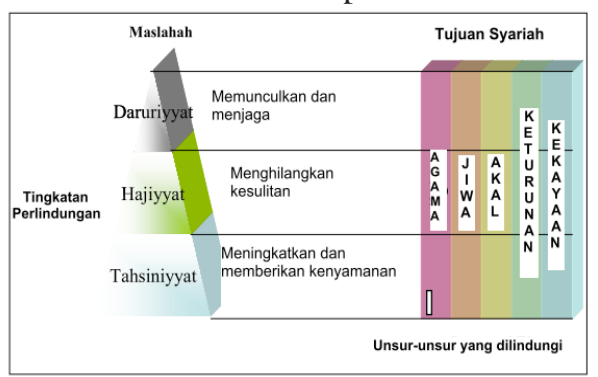

Gambar 1. Hubungan antara konsep maslahah dan maqasid al shari'ah 


\section{Peace Education sebagai Cara Pencegahan Kekerasan}

Peace (perdamaian) menyiratkan sebuah upaya untuk menyelesaikan berbagai macam konflik, memperlakukan orang lain dengan penuh rasa hormat, dan membangun sebuah kesepakatan. Secara lebih luas, Harris menyatakan bahwa, "Peace", konsep yang memotivasi imaginasi, mengkonotasikan lebih dari hanya sekadar penghentian perang. Ia menyiratkan manusia yang bekerjasama untuk memecahkan konflik, menghormati keadilan, memenuhi kebutuhankebutuhan dasar, dan menghargai hak asasi manusia (Harris, 1990: 255).

Sedangkan education tidak hanya mengarah kepada pendidikan formal, namun harus dipahami sebagai sebuah "sistem pesan" yang mencakup kurikulum, pedagogi dan evaluasi. Dari pemahaman ini, peace education (pendidikan perdamaian) menyiratkan sebuah pendidikan berorientasi nilai yang ditujukan untuk mewujudkan sebuah dunia yang lebih diinginkan. Kurikulumnya membahas isu-isu perdamaian dan faktor-faktor yang menghambat terwujudnya perdamaian. Pedagoginya berupaya mencari metode-metode yang tepat untuk mentransmisikan pengetahuan ini. Evaluasinya dilakukan melalui sudut pandang: belajar, bertindak, dan merefleksi. Yaitu, bagaimana pengetahuan diwujudkan melalui perubahan sikap dan perilaku pada masing-masing individu dan merefleksikan tindakan-tindakan mereka untuk menciptakan perubahan-perubahan yang mengandung perdamaian dalam masyarakat, negara dan dalam tingkatan yang lebih tinggi, dunia.

Untuk menciptakan perdamaian, seorang pendidik harus mengembangkan satu metode pengajaran atau pedagogi tertentu, yang dapat digunakan di dalam kelas. Menurut prinsip pedagogi perdamaian, peserta didik dapat belajar bagaimana menghadirkan perdamaian ke dunia tidak hanya dengan mempelajari isu-isu tentang perang dan perdamaian, namun juga mempelajari kemampuan, perilaku, bakat di lingkungan kelas, yang dibangun melalui cara seorang pendidik menstruktur pelajaran-pelajarannya.

Menurut pedagogi perdamaian, kelas harus dibangun melalui lima prinsip utama: dialog, kerjasama, pemecahan masalah, afirmasi, dan pembentukan batasan demokratis. Dialog mengarah kepada bagaimana seorang pendidik memberikan informasi; kerjasama mengarah kepada lingkungan belajar yang dibangun oleh seorang pendidik; pemecahan masalah merujuk kepada pembentukan keterampilan (building skill) yang dapat digunakan oleh peserta didik untuk memecahkan problem kekerasan; afirmasi mengarah kepada motivasi. Seorang pendidik menggunakan teknik motivasi untuk menginspirasi minat pada isu-isu yang terkait dengan perdamaian dan standar-standar pembentukan 
kepercayaan diri untuk membantu peserta didik menghadapi dengan berani ancaman-ancaman kekerasan yang menghantui dunia. Pembentukan batasan demokratis mengarah kepada metode untuk menjaga kelas tetap menghargai batasan-batasan dan persoalan-persoalan dari masing-masing anggota kelas (Harris, 1990: 255-256).

Prinsip-prinsip pedagogi perdamaian ini dapat menciptakan dalam kelas sebuah komunitas yang penuh kepedulian, yang mengajarkan peserta didik untuk menghargai prinsip-prinsip demokrasi dan melawan asumsi-asumsi kekerasan yang mendasari pedagogi tradisional yang berpusat pada guru.

\section{Pengajaran Usul al fiqh Berbasis Peace Education}

Pengajaran adalah suatu proses transmisi pengetahuan dan nilai dari pendidik kepada peserta didik. Agar sebuah transmisi pengetahuan ini berjalan efektif, maka pendidik perlu berangkat dari suatu pendekatan, dan memformulasi sebuah metode pengajaran. Dalam pedagogi pengajaran usul al fiqh berbasis peace education, pendekatan yang perlu diambil dapat mencakup dua prinsip ini.

\section{Mendorong Sikap Hormat terhadap Perbedaan}

Satu pertanyaan penting dalam pendidikan perdamaian adalah bagaimana memastikan bahwa para peserta didik dapat menghadapi perbedaan-perbedaan dengan cara-cara yang positif, karena pelbagai pertemuan dan interaksi dengan perbedaan ini berpotensi mengantarkan kepada kekerasan dan ketidakadilan. Hookway, seperti dikutip Bischoff dan Moore (2007: 153), menawarkan sebuah skema yang dapat membantu mengatur ragam pendekatan terhadap perbedaan, dengan menggambarkan pendidikan sebagai cermin (mirror), jendela (window), dan percakapan (conversation).

Pendidikan sebagai "cermin" merupakan bagian penting untuk mempersiapkan para peserta didik dalam menghadapi perbedaan. Dalam kaitan ini, memahami seseorang dan lingkungannya adalah penting untuk dapat terlibat secara positif dalam perbedaan. Alasannya adalah bahwa menggunakan pengalaman langsung seseorang tidaklah bersifat memaksa dan mengandung kekerasan. Pengetahuan tentang diri sendiri, yang disandingkan dengan interaksi dan pertemuan dengan berbagai bentuk perbedaan, membantu seseorang menjauhi pemaksaan pandangan terhadap orang lain (Bischoff dan Moore, 2007: 154).

Pendidikan sebagai "jendela” mengandung pengertian, mengajarkan 
kepada peserta didik berbagai tradisi keagamaan yang berbeda dengan segala keunikannya. Pendidikan semacam itu dapat meningkatkan dan memupuk kebebasan beragama dan perbedaan tanpa intoleransi yang mengandung kekerasan. Selain itu, pengalaman-pengalaman pribadi dengan orang lain yang berbeda dalam hal gender, latarbelakang sosial ekonomi, dan warisan budaya adalah sangat penting demi membangun relasi dengan orang lain dan lingkungan sekitar dengan penuh rasa hormat dan kepedulian. Para peserta didik, singkatnya, perlu mempunyai pendidikan dalam perspektif tradisi keberagamaan mereka sendiri dan juga lintas agama dan keyakinan (Bischoff dan Moore, 2007: 154). Pendidikan sebagai "percakapan”. Maksudnya, percakapan dinilai sebagai dialog yang bermakna antara dua pihak, yang dalam situasi tersebut masing-masing terbuka pada perubahan (Bischoff dan Moore, 2007: 155).

\section{Melakukan Aktivitas yang Lebih Kooperatif Ketimbang Kompetitif}

Pembelajaran yang kooperatif mengarah kepada pemahaman bahwa peserta didik bekerja bersama-sama dalam sebuah kelompok kecil untuk membantu diri mereka dan orang lain untuk belajar (McInnerney dan Roberts, 2004: 205), atau sebuah metode belajar yang menggunakan interaksi sosial sebagai media untuk membangun pengetahuan (Paz Dennen, 2000). Pentingnya penggunaan aktivitas kooperatif didasari pada penelitian yang menunjukkan bahwa teknik pembelajaran kooperatif lebih unggul dalam meningkatkan hasil belajar dibandingkan dengan pengalaman-pengalaman belajar individual atau kompetitif (Haris, 1990: 263). Tugas-tugas belajar yang kompleks seperti pemecahan masalah, berpikir kritis, dan pembelajaran konseptual meningkat secara nyata pada saat digunakan strategi-strategi kerja sama. Peserta didik lebih memiliki kemungkinan menggunakan tingkat berpikir yang lebih tinggi selama dan setelah diskusi dalam kelompok kooperatif ketimbang mereka bekerja secara individual atau kompetitif. Selain itu, peserta didik dapat memperoleh manfaat-manfaat emosional dan keterampilan sosial dari kelas yang kooperatif. Mereka cenderung melihat teman-temannya secara lebih baik. Kondisi saling menyukai yang dimunculkan dari bekerja sama meningkatkan motivasi untuk belajar.

Prinsip pembelajaran kelas yang kooperatif dapat digunakan untuk usul al figh dengan membentuk kelompok-kelompok peserta didik, yang dalam kelompok tersebut mereka dapat saling belajar, ketika mengeksplorasi berbagai isu bersama-sama. Kelompok-kelompok informal dapat digunakan di tengah 
perkuliahan untuk membantu peserta didik memproses apa yang mereka telah dipelajari. Kelompok fokus yang terdiri dari dua atau tiga peserta didik dapat digunakan untuk memunculkan pertanyaan-pertanyaan sebelum presentasi dan dapat membantu para peserta didik memperoleh informasi pada akhir presentasi. Pengelompokan peserta didik secara informal membuat mereka dapat memproses secara aktif apa yang telah dan sedang mereka pelajari dan memudahkan pendidik untuk mendengar diskusi-diskusi ini demi mengumpulkan informasi yang penting tentang bagaimana pelbagai konsep tersebut diterima dan dipahami. Kelompok-kelompok yang lebih formal dapat digunakan dalam wilayah-wilayah tertentu, untuk mengkaji ulang pekerjaan rumah, atau menyelesaikan sebuah masalah secara bersama-sama (lihat bagan berikut).
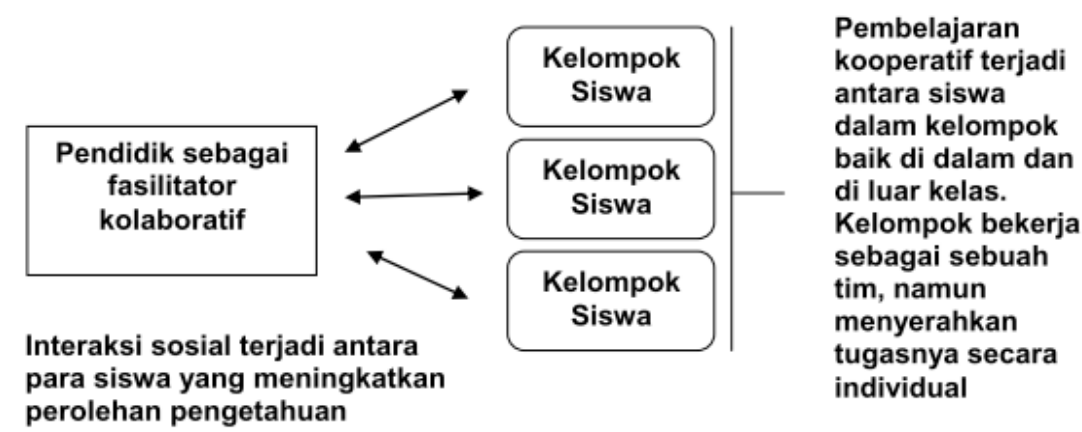

Gambar 2. Model pembelajaran kooperatif di dalam kelas

\section{Metode Pengajaran di Kelas}

Pengajaran usul al figh berbasis pendidikan perdamaian (peace education) dapat menggunakan berbagai cara sebagai berikut:

1. Dialog

Dalam kelas yang disusun berdasarkan pada prinsip-prinsip dialog ini, pendidik dan peserta didik bersama-sama membagi informasi, merespons pengalaman yang sama dan mencari jawaban terhadap pertanyaan-pertanyaan yang sulit. Setiap peserta didik menyumbangkan pandangan-pandangannya untuk mengkonstruk kebenaran. Kuncinya adalah saling menukar gagasan, yang masing-masing menghargai pendapat yang lainnya. Pendidik belajar dari peserta didik, dengan memberikan tugas kepada mereka untuk membaca dan meneliti dunia mereka budaya, adat kebiasaan, dan tradisi pengetahuan. Para peserta didik mengemukakan wawasan mereka tentang dunia tersebut kepada kelas, dan pendidik menggunakan metode dialog untuk bertanya kepada 
peserta didik mengenai wawasan-wawasan tersebut.

Dalam kaitan dengan pengajaran usul al fiqh, pendidik menyajikan satu persoalan kepada para peserta didik, yang masing-masing memberikan berbagai jawaban. Misalnya, pendidik sebagai peserta dan fasilitator mengangkat isu tentang "bom bunuh diri", sedangkan para peserta didik merespons masalah ini dengan memberikan jawaban-jawaban berdasarkan metodologi usul al fiqh yang telah dipelajarinya. Peserta didik dapat menghadirkan berbagai metode penalaran hukum yang relavan untuk memecahkan persoalan tersebut, apakah dengan menggunakan qiyas, istislah atau mungkin pula maqasid al shari'ah. Begitu seterusnya dalam isu-isu yang lain.

\section{Kerjasama}

Belajar kooperatif merupakan model belajar dengan peserta didik dalam kelompok kecil yang heterogen terdiri dari 4-6 orang untuk menyelesaikan tugas dan memecahkan masalah serta untuk mencapai tujuan kelompok yang saling menguntungkan. Penekanan pada belajar kelompok adalah aspek sosial, yaitu adanya aktivitas sosial, yaitu adanya aktivitas tiap anggota kelompok untuk berinteraksi dengan anggota yang lain, dan pendidik berupaya mengkondisikannya dengan selalu memotivasi peserta didik agar tumbuh rasa kebersamaan dan saling membutuhkan di antara peserta didik.

Dalam menyelesaikan tugas kelompok setiap anggota saling bekerja sama secara kolaboratif dan membantu untuk memahami suatu materi, memeriksa dan memperbaiki pekerjaan teman serta kegiatan lainnya, dengan tujuan mencapai hasil belajar yang tinggi. Ditanamkan pemahaman kepada peserta didik bahwa tugas belum selesai apabila salah satu anggota kelompok belum menguasa dan memahami materi pembelajaran.

Dalam pengajaran usul al fiqh, langkah-langkah pembelajaran dapat disajikan secara lebih jelas dalam tabel berikut:

Tabel 3. Langkah-langkah pembelajaran kooperatif dalam pengajaran usul al figh

\begin{tabular}{|l|l|}
\hline \multicolumn{1}{|c|}{ Fase } & \multicolumn{1}{c|}{ Kegiatan } \\
\hline Fase 1 & Pendidik menyampaikan tujaun \\
Menyampaikan tujuan dan & $\begin{array}{l}\text { pembelajaran yang ingin dicapai pada } \\
\text { pelajaran tersebut dan memotivasi peserta } \\
\text { didik }\end{array}$ \\
\hline Fase 2 & $\begin{array}{l}\text { Pendidik menyajikan informasi kepada } \\
\text { siswa dengan jalan demonstrasi atau lewat } \\
\text { bahan bacaan. }\end{array}$ \\
\hline
\end{tabular}




\begin{tabular}{|l|l|}
\hline Fase 3 & $\begin{array}{l}\text { Pendidik menjelaskan kepada peserta } \\
\text { didik bagaimana caranya membentuk } \\
\text { kelompok belajar dan membantu setiap } \\
\text { kelompok agar melakukan komunikasi } \\
\text { secara efisien }\end{array}$ \\
\hline $\begin{array}{l}\text { Fase } 4 \\
\text { Membimbing kelompok bekerja } \\
\text { dan belajar }\end{array}$ & $\begin{array}{l}\text { Pendidik membimbing kelompok- } \\
\text { kelompok belajar pada saat mereka } \\
\text { mengerjakan tugas }\end{array}$ \\
\hline $\begin{array}{l}\text { Fase 5 } \\
\text { Evaluasi }\end{array}$ & $\begin{array}{l}\text { Pendidik mengevaluasi hasil belajar } \\
\text { tentang materi yang dipelajari atau masing- } \\
\text { masing kelompok mempresentasikan hasil } \\
\text { kerjanya }\end{array}$ \\
\hline $\begin{array}{l}\text { Fase 6 } \\
\text { Memberikan penghargaan }\end{array}$ & $\begin{array}{l}\text { Pendidik mencari cara-cara untuk } \\
\text { menghargai baik upaya maupun hasil } \\
\text { belajar individu dan kelompok }\end{array}$ \\
\hline Sumbeling
\end{tabular}

Sumber: Ibrahim, et. al (2000).

\section{Pemecahan Masalah}

Pendekatan belajar "problem solving" atau metode pemecahan masalah atau belajar berbasis pada masalah merupakan salah satu alternatif untuk mempermudah belajar siswa sehingga lebih bermakna dan berdaya guna. Belajar dengan menggunakan pendekatan pemecahan masalah berusaha untuk menciptakan kondisi belajar yang berorientasi pada proses dan berpusat pada siswa. Pemecahan masalah sebagai sebuah pendekatan belajar melibatkan lingkungan belajar, yang di dalamnya masalah adalah kunci untuk menuju proses belajar, yaitu sebelum siswa belajar sejumlah pengetahuan, terlebih dahulu mereka diberikan masalah.

Pendekatan belajar ini diawali dengan pertanyaan-pertanyaan di sekitar topik-topik usul al figh yang sedang dipelajari dan kemudian dihubungkan dengan persoalan-persoalan yang muncul dalam kehidupan masyarakat sekarang. Kemudian peserta didik melaksanakan tahap-tahap pembelajaran dengan menggunakan langkah-langkah disain pemecahan masalah. Secara umum, proses belajar berlangsung dari identifikasi masalah, perumusan masalah, mencari solusi, mendiskusikan solusi, dan evaluasi (pembuatan keputusan).

\section{Afirmasi}

Dalam ruangan kelas, tindakan afirmasi membantu mengembangkan kompetensi. Dengan memperkuat prestasi peserta didik, afirmasi dapat 
meningkatkan rasa percaya diri dan membantu mereka merasa disukai dan dihargai. Mengapa afirmasi begitu penting? Karena manusia membutuhkan spirit, baik yang datang dari diri sendiri maupun dari luar. Spirit dari luar diri manusia adalah semacam dorongan yang membuat para peserta didik dapat lebih percaya diri. Peserta didik yang meningkatkan rasa percaya dirinya dalam kelas-kelas yang berbasis pada pendidikan perdamaian mungkin akan belajar mempercayai pandangan-pandangan mereka dan mempunyai keberanian untuk mengambil resiko untuk menentang segala bentuk kekerasan.

\section{Pembuatan Batasan Demokratis (Democractic Boundary Setting)}

Penciptaan perdamaian adalah tentang pembentukan batasan-batasan yang menghilangkan segala bentuk permusuhan dan menghargai batasanbatasan orang lain. Kekerasan muncul karena adanya pelanggaran terhadap batasan-batasan yang dibuat oleh orang lain. Maka, para pendidik, dengan mengelola kelasnya sedemikian rupa, harus menyediakan pelajaran-pelajaran penting tentang penciptaan dan pemeliharaan terhadap batasan-batasan tersebut. Mereka menyadari tentang keharusan adanya prosedur untuk mengatur perilaku di dalam kelas-siapa yang membuat aturan-aturan, bagaimana aturan-aturan tersebut dijalankan, dan apa yang terjadi terhadap mereka yang melanggar aturan-aturan tersebut. Sebuah kelas tanpa aturan akan mengalami kekacauan, sebagaimana dunia tanpa hukum dapat menjadi anarkis (Harris, 1990: 266).

Pembuatan batasan demokratis tentu saja mengundang para peserta didik untuk ikut dalam proses pembuatan aturan, dengan menjelaskan kepada mereka pentingnya membuatan batasan-batasan terhadap perilaku yang dapat diterima dan mendorong siswa untuk berpartisipasi dalam menciptakan aturan-aturan yang menghargai batasan-batasan orang lain yang terkait. Prosedur tersebut mendorong para pendidik untuk menjalankan kelas,yang memberikan faslitas bagi pembuatan agenda di pihak peserta didik, ketimbang mendominasi pembelajaran dengan agenda yang telah diatur.

Sebagai metode disiplin kelas, democractic boundary setting berasumsi bahwa semua orang yang ada dalam kelas mempunyai batasan-batasan tertentu. Misalnya, tidak boleh teriakan yang membuat seorang tidak bisa mendengar dengan baik; para peserta didik harus saling mendengarkan satu dengan yang lainnya; peserta didik tidak boleh datang terlambat ke kelas; peserta didik harus mempersiapkan pelajarannya, dan seterusnya. Dalam kelas yang dibangun pada prinsip perdamaian, pendidik harus mendiskusikan batasan-batasan apa yang 
harus dipatuhi oleh peserta didik dan menjelaskan batasan-batasan bagi seorang pendidik. Setelah itu, kelas harus sepakat tentang batasan-batasan tertentu atau menerima batasan-batasan yang dibuat bagi perilaku-perilaku tertentu. Misalnya, dalam memberikan nilai pada pekerjaan siswa, pendidik harus menyerahkan tugas tersebut tepat waktu; dalam mempersiapkan diskusi kelas, semua peserta didik sepakat untuk mengerjakan tugas-tugas mereka. Batasanbatasan ini akan membantu peserta didik mendefinisikan perilaku-perilaku yang dapat diterima. Ketika batasan tersebut disepakati, maka pendidik dan anggota kelas harus membuat aturan-aturan yang mengekspresikan batasanbatasan ini dan menghargai batasan orang-orang yang ada dalam kelas.

Prosedur demokratis ini memberikan kontrol kepada peserta didik terhadap lingkungan belajar mereka dan memungkinkan pendidik untuk membuat norma-norma yang jelas bagi perilaku yang diterima dan tidak. Ketika norma-norma ini dilanggar, siapa pun di kelas dapat menunjukkannya dan memberikan hukuman yang berhubungan dengan pelanggaran terhadap aturan-aturan ini. Aturan harus mempunyai karakteristik, dan harus dipahami dan diketahui oleh semua orang dalam kelas. Mereka harus tahu apa yang terjadi jika aturan-aturan tersebut dilanggar, dan semua anggota kelas dapat bertanggung jawab untuk menjalankan aturan-aturan yang diterima secara umum.

Pemeliharaan batasan-batasan yang harmonis di kalangan masyarakat adalah salah satu tujuan inti perdamaian. Dengan menjelaskan kepada peserta didik tentang pentingnya membuat aturan-aturan yang memberikan kemudahaan kepada kelas untuk mencapai tujuan-tujuan pembelajarannya, dan dengan melibatkan para peserta didik dalam penyusunan aturan-aturan ini, para peserta didik diajarkan tentang bagaimana membuat aturan-aturan dalam cara yang bertanggung jawab secara sosial yang menghargai hak-hak orang lain. Memasukkan pandangan-pandangan yang berbeda akan menghargai batasan-batasan orang lain dan akan memperagakan perilaku demokratis peserta didik yang mereka gunakan dalam keluarga dan pekerjaan mereka.

\section{Simpulan}

Dari uraian di atas dapat disimpulkan bahwa pedagogi usul al figh berbasis pendidikan perdamaian dapat dieksplorasi dalam dua prinsip mendasar, yaitu mendorong sikap hormat terhadap perbedaan, dan melakukan aktivitas yang lebih kooperatif ketimbang kompetitif. Prinsip pertama dapat dijalankan dengan melihat pendidikan sebagai cermin, jendela dan percakapan. Prinsip kedua 
dengan menciptakan ruangan kelas yang mendasarkan pada cooperative learning. Dua prinsip ini dapat dijalankan dengan menggunakan metode pengajaran seperti dialog, kerjasama, pemecahan masalah, afirmasi, dan pembentukan batasan demokratis.

\section{Daftar Pustaka}

Al Ghazali, Abu Hamid Muhammad. 1993. al Mustasfa min 'Ilm al Usul. Jilid 2. Jiddah: Sharikah al Madinah al Munawwarah.

Al Namlah, 'Abd al Karim Ibnu 'Ali Ibnu Muhammad. 1999. al Muhadhdhab fi 'Ilm Usul al figh al Muqaran. Volume 1. Riyad: Maktabah al Rushd.

Al Nisaburi, Abu al Husayn Muslim Ibnu al Hajjaj al Qushayri. 1991. Sahih Muslim. Jilid 1. Beirut: Dar al Kitab al 'Ilmiyyah.

Al Sa'di, 'Abd al Hakim 'Abd al Rahman As'ad. 2000. Mabahith al 'Illah fi al Qiyas 'Inda al Usuliyyin. Beirut: Dar al Basha'ir al Islamiyyah.

Al Zuhayli, Wahbah. 1986. Usul al figh al Islami, Jilid 1 dan 2. Damaskus: Dar al Fikr.

Bischoff, Claire dan Moore, Mary Elizabeth Mullino. 2007. Cultivating A Spirit for Justice and Peace: Teaching Through Oral History. Religious Education. Volume 102. Nomor 2: 151-171.

Hallaq, Wael B. 2001. Authority, Continuity and Change in Islamic Law. Cambridge: Cambridge University Press.

Harris, Ian M. 1990. Principles of Peace Pedagogy. Peace and Change. Volume 15, Nomor 3: 254-271.

Ibrahim, M. et.al. 2000. Pembelajaran Kooperatif. Surabaya: Universitas Negeri Surabaya Press.

Jenkins, Wilis. 2005. Islamic Law and Environmental Ethics: How Jurisprudence (Usul al fiqh) Mobilizes Practical Reform. Wordviews. Volume 9, Nomor 3: 338-364.

Kamali, Mohammad Hashim. 2008. Shari'ah Law: An Introduction. Oxford: Oneworld.

McInnerney, Joanne M. dan Roberts, Tim S. 2004. Collaborative or Cooperative 
Learning? Dalam Tim S. Roberts. Online Collaborative Learning: Theory and Practice. USA: Information Science Publishing.

Paz Dennen, V. 2000. Task Structuring for Online Problem-Based Learning: A Case Study. Educational Technology ES Society. Volume 3, Nomor 3: 329-336.

Sanu, Qutb Mustafa. 2000. Mu’jam Mustalahat Usul al fiqh. Damaskus: Dar al Fikr.

Shahrur, Muhammad. 2000. Nahwa Usul Jadidah li al figh al Islami. Damaskus: al Uhali.

Waugh, Earle H. 2004. Peace. Dalam Jane Dammen McAuligge (Ed.). Vol. 4. Leiden: Brill. 